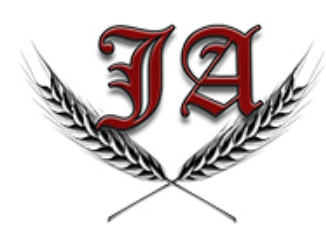

JOURNAL of AGRICULTURE

agrijournal@hotmail.com

ISSN: 2636-8757

https://dergipark.org.tr/tr/pub/ja

DOI: $10.46876 /$ ja.915923

Research / Araştırma

\title{
Antioxidant Effect of Achillea biebersteinii in Different Extracts and Extinguhishing Activity on DPPH
}

\author{
Duygu DOĞAN ${ }^{*}$, İsmet MEYDAN ${ }^{2}$
}

\begin{abstract}
Achillea biebersteinii (A. biebersteinii), one of the Achillea species, has been proven to have positive effects in terms of pharmaceuticals thanks to the components it contains. Our study was designed to investigate the quenching activity of $A$. biebersteinii on total phenolic component, total flavonoid component and DPPH radical. The total flavonoid component amounts of the ethanol and water extract of $A$. biebersteinii plant were calculated to be equivalent to quercetin, and the total phenol component amounts to gallic acid. The DPPH radical quenching activity of the ethanol and water extract of the A. biebersteinii plant was investigated by modifying the Teixeira method. The copper II ion reduction method (CUPRAC) is inspired by the Apak method. We can say that the water and alcohol extract of $A$. biebersteinii gave good results compared to BHA and BHT, which have good quenching activity on DPPH radical. It was observed that $A$. biebersteinii was rich in flavonoids and phenolics. As a result of Cuprac analysis, it was stated that the effect of the aqueous extract was significant compared to the positive controls. The $A$. biebersteinii plant is thought to be effective in the treatment of many diseases, especially cancer, due to its powerful antioxidant and radical quenching activity..
\end{abstract}

Keywords: Achillea biebersteinii, Phenolic, Flavonoid, Cuprac, Antioxidant

Achillea biebersteinii'nin Farklı Ekstraktlarda Antioksidan Etkisi ve DPPH Üzerindeki Söndürme Aktivitesi

\section{ÖZET}

Achillea türlerinden biri olan Achillea biebersteinii (A. biebersteinii), içerdiği bileşenler sayesinde farmasötik açıdan olumlu etkilere sahip olduğu kanıtlanmıştır. Çalışmamız, A. biebersteinii'nin toplam fenolik bileşen, toplam flavonoid bileşen ve DPPH radikali üzerindeki söndürme aktivitesini araştırmak için tasarlanmıştır. A. biebersteinii bitkisinin etanol ve su ekstraktının toplam flavonoid bileşen miktarları quercetin'e, toplam fenol bileşen miktarları ise gallik aside eşdeğer olarak hesapland. A. biebersteinii bitkisinin etanol ve su özütünün DPPH radikal söndürme aktivitesi Teixeira yöntemi değiştirilerek araştırıldı. Bakır II iyon azaltma yöntemi (CUPRAC), Apak ve arkadaşlarının çalışmalarından esinlenerek yapılmıştır. A. biebersteinii'nin su ve alkol özütünün, DPPH radikali üzerinde iyi söndürme aktivitesine sahip olan BHA ve BHT'ye kıyasla iyi sonuçlar verdiğini söyleyebiliriz. A. biebersteinii' nin flavonoidler ve fenolikler açısından zengin olduğunu görüldü. Cuprac analizi sonucunda sulu ekstrenin etkisinin pozitif kontrollere göre önemli olduğu belirtildi. A. biebersteinii bitkisinin, güçlü antioksidan ve radikal söndürme aktivitesinden dolayı başta kanser olmak üzere birçok hastalığın tedavisinde etkili olduğu düşünülmektedir.

Anahtar Kelimeler: Achillea biebersteinii, Fenolik, Flavonoid, Kuprak, Antioksidan

\footnotetext{
${ }^{1}$ Duygu DOĞAN (Orcid ID: 0000-0001-8338-9063), Van Yüzüncü Y1l University, Faculty of Science, Department of Chemistry, Zeve Campus, 65800,

Van, Turkey

2 İsmet MEYDAN (Orcid ID: 0000-0001-5640-6665), Van Yüzüncü Y1l University, Van Vocational School of Health Services, Zeve Campus, 65800, Van,

Turkey

*Sorumlu Yazar/Corresponding Author: Duygu DOĞAN, e-mail: dyg.gms1905@hotmail.com 


\section{INTRODUCTION}

The defense systems that work in the body to prevent the formation of reactive oxygen species, prevent the damage caused by these substances and provide detoxification are called antioxidant defense systems or antioxidants. Antioxidants are substances that react very quickly with radicals and prevent the progress of oxidation and peroxidation. The roles of antioxidants include neutralizing excess free radicals, protecting cells against toxic effects of free radicals, and contributing to disease prevention. Studies have proven that plants have especially phenolic, flavonoid and many other antioxidant-rich components (Altındağ and Özdek, 2021; Meydan and Seckin, 2021).

Free radicals are known to cause many diseases, especially cancer. It has been proven that antioxidants in plants have preventive effects against these diseases (Sökmen et al., 2004; Ayeygin et al., 2020). It has been shown that plant extracts prevent the oxidative process, protect against diabetes and have antimicrobial effects (Özdek et al.,2020). In a previous study, it was revealed that evening primrose oil reduced oxidative stress in rats with metabolic syndrome (Mert et al.,2020). Plants are important bioactive products that attract attention in the field of pharmacology thanks to the phenolic compounds they contain. It is preferred in cosmetics, health and food sectors thanks to the essential oils in the plant. (Lobo et al., 2010; Altindağ and Rağbetli, 2021).

Achillea, one of the plant genera, is one of the most important species of the Asteraceae family and there are more than 100 species in the world (Mirahmadi et al., 2017). It has many varieties in Europe, West Asia, New Zealand and North America. Apart from this, this medicinal herb, which is found in different regions of Iran, is also used in hypoglycemic, anti-hemorrhoid, anti-diarrheal antacid, carminative, anthelmintic and antibacterial, antimicrobial drugs (Kojourian et al., 2017). We also see the effect of Achillea species preventing the formation of oxidative stress by eliminating free radicals. A. biebersteinii is called yellow flower. This perennial plant has erect stems with a height of 30-60 cm (Akkol et al., 2011). It is used as a natural remedy for pain and wounds among the public (Barış et al., 2006).

In an antibacterial study on the plant of $A$. biebersteinii, it was seen to have a sensitive effect on the bacteria used (Hammad et al., 2013). In another study in which essential oil and methanol extracts were used, it showed an antimicrobial effect and proved its antioxidant activity to be positive as a result of the tests. In the research conducted on gastric ulcers, protective and therapeutic results against the stomach were obtained (Abd-Alla et al., 2016). A. biebersteinii has shown that it is an alternative for treatment in a study conducted as a new drug candidate on anticholinesterase molecules (Sevindik et al., 2015).

\section{MATERIALS AND METHODS}

\section{Preparation of plant extract}

A. biebersteinii, which has been used in traditional medicine for a long time, is known as yarrow (Baharara et al., 2015). A. biebersteinii, whose leaves are up to $10 \mathrm{~cm}$, is also used as a folk remedy to increase appetite and stop bleeding (Yıldırım et al., 2015). The plant, which was properly collected from Van, was first washed with tap water and then pure water. After drying at room conditions and grinding, $50 \mathrm{~g}$ of samples were taken and dissolved in $250 \mathrm{ml}$ of ethyl alcohol. Ethyl alcohol was removed by evaporator. The solid material obtained was stored at +4 degrees for study.

\section{Determination of total phenolic contents}


Total phenolic determination of $A$. biebersteinii was determined according to the FolinCiocalteu method (Alhakmani et al., 2013). Distilled water and methanol were added to $0.04 \mathrm{ml}$ of the plant mixture. It was incubated for 2 hours by adding $20 \% \mathrm{Na}_{2} \mathrm{CO}_{3}$ diluted with $0.2 \mathrm{ml}$ of FolinCiocalteu reagent. It was measured at $765 \mathrm{~nm}$ absorbance value and compared with the gallic acid calibration curve.

$$
\left(y=315.56 x+28.202 R^{2}=0.9983\right)
$$

Total phenols were evaluated on gallic acid (mg gallic acid / g dry weight).

\section{Antioxidant activity (DPPH)}

The radical scavenging activities of the samples were adapted according to the DPPH method (Teixeira et al., 2013). DPPH and the same ratio extract solutions were prepared in 5 different concentrations as 25,50,100, 200 and $250 \mu \mathrm{g} / \mathrm{ml} .3 \mathrm{ml}$ of plant extract and positive control were taken and DPPH solution was added on them. The mixtures formed in the tubes were left to incubate for 30 minutes in the dark and at room temperature. At the end of this period, absorbance values were read at $517 \mathrm{~nm}$.

$$
\% \mathrm{I}=[(\text { Akontrol-Aample }) / \text { Akontrol }] \times 100
$$

As a result of these processes, a graph of $A$. biebersteinii -water, A. biebersteinii -alcohol concentration was obtained, With the increasing DPPH ethanol concentration. The graph is based on the equation above.

\section{Total flavonoid component amount determination}

The component determination of $A$. biebersteinii ethanol and water extract was made by adapting from the work that previously determined this method (Zhishen et al., 1999). Quarcetin is used as a standard. $0.1 \mathrm{ml}$ of $10 \% \mathrm{Al}\left(\mathrm{NO}_{3}\right)_{3}, 0.1 \mathrm{ml}$ of $1 \mathrm{M} \mathrm{KCH} \mathrm{KCOO}_{3} \mathrm{CO}$ - and $3.8 \mathrm{ml}$ of methanol were added to the A. $1 \mathrm{ml}$ of quarcetin and $1 \mathrm{ml}$ of extract are added to the prepared tubes and mixed. The mixtures obtained were incubated at $25{ }^{\circ} \mathrm{C}$ for 40 minutes. Then, absorbances at $415 \mathrm{~nm}$ were read.

\section{Total antioxidant capacity cuprac test}

The CUPRAC test, which is the copper ion-reducing antioxidant capacity method(Apak et al., 2004), is a selective assay based on electron transfer. The redox reagent used is bis (neocuproin) copper (II) chelate. The reagent, showing its effectiveness at $\mathrm{pH} 7.0$, gives $450 \mathrm{~nm}$ measurement (Özyürek et al., 2011). In this study, neocuproin solution was prepared with $1 \mathrm{ml}$ copper (II) chloride, $1 \mathrm{ml}$ ammonium acetate buffer (at $\mathrm{pH} \mathrm{7,0).} \mathrm{The} \mathrm{mixture} \mathrm{was} \mathrm{left} \mathrm{for} 30$ minutes and was read against the empty reagent at $450 \mathrm{~nm}$. Then, the samples with extracts were incubated at $50{ }^{\circ} \mathrm{C}$ for 20 minutes, and then measured at $450 \mathrm{~nm}$ absorbance.

\section{RESULTS AND DISCUSSION}

\section{Determination of total phenolic contents}

Phenolic compounds in plant ingredients contribute significantly as antioxidants. Studies show that there is a positive relationship between phenolic compounds and antioxidant activity (Meydan et al., 2020). In the comparative study of Achillea phrygia, it was observed that the 
phenolic content of the methanol extract was found to be $41.13 \pm 0.74$ (mg GAE /g extract) and that it had a higher content than the other plant compared to it (Zengin et al., 2017). In another study conducted on different parts of Achillea millefolium plant, we see that the highest phenolic value was in flower-ethanol (19.30 PETP (mg)) (Keser et al., 2013).

Achillea species with a wide range of phenolic content are important for evaluation. In our study, we confirmed that both other species and A. biebersteinii have these complexes. When we compare it between its types, we see that it has a rich content. We found that the total phenolic content of $A$. biebersteinii ethanol and water extract was equivalent to the gallic acid we determined according to the Folin-Ciocalteus method. The absorbance values against the increasing absorbance value of gallic acid were plotted. It has been determined that it shows its high efficiency more in ethyl alcohol extract.

Table 1. Water and ethyl alcohol total phenolic component content

Total phenolic ( $\mu$ g GEs/mg extract)*
Water ekstract
$420.4431 \pm 20.2478$

Ethyl alcohol

$131.7057 \pm 21.7457$

*: PEs, gallic asid equivalents ( $\left.\mathrm{y}=315,56 \mathrm{x}+28,202 \mathrm{R}^{2}=0.9983\right)$.

Values are given as the mean and standard deviation of 3 parallel measurements.

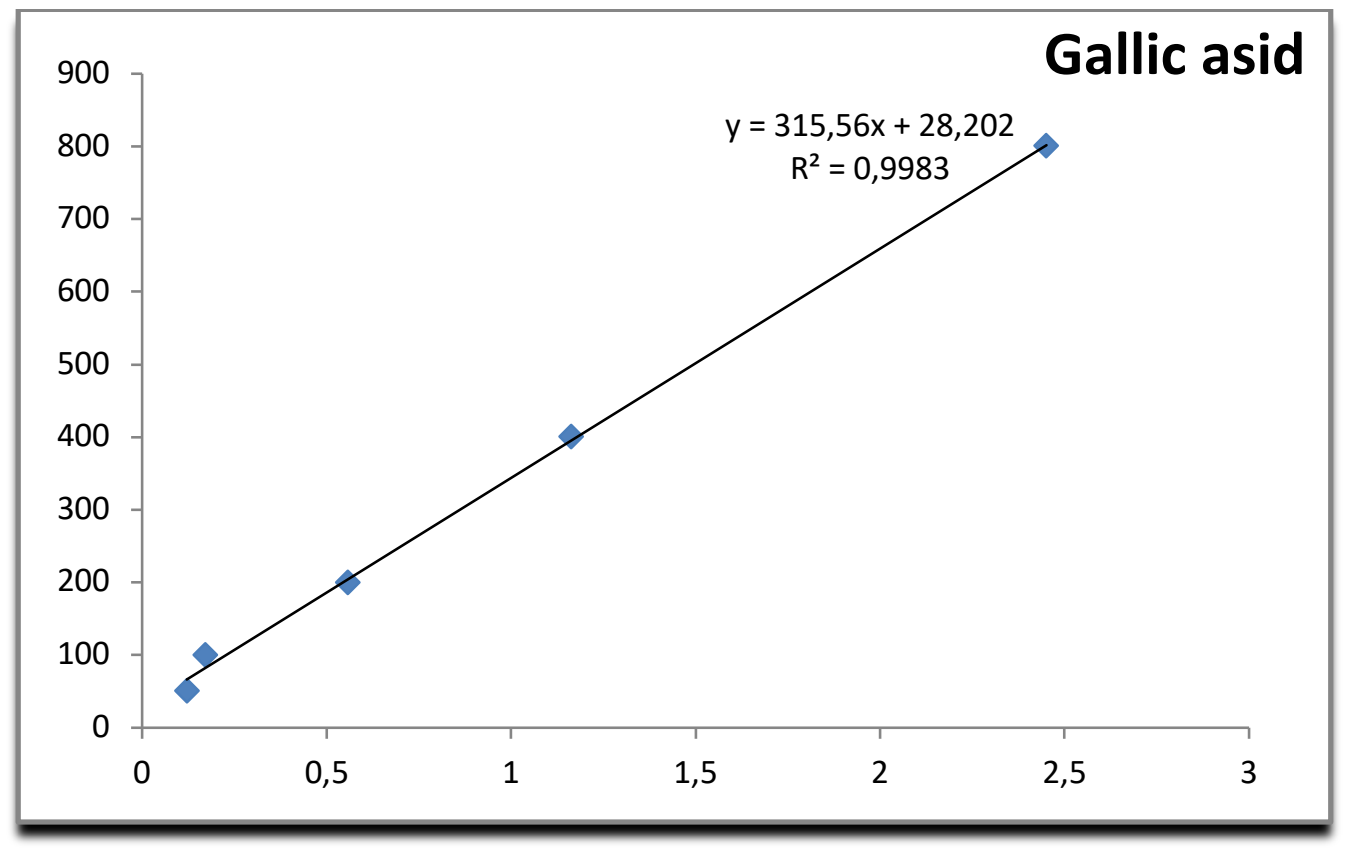

Figure 1. Gallic acid standard chart for total phenolic. The coefficient of determination $\left(\mathrm{R}^{2}\right)$, which expresses the explanatory power of the model, was found to be 0.9983

\section{Antioxidant activity (DPPH)}

DPPH, which depends on a characteristic absorption, is a spectrophotometric method used for radical scavenging. With the plant extract providing $\mathrm{H}$ atoms, there is a significant decrease in the reduced radical (Oke et al., 2009; Mirahmadi et al., 2017). The radical scavenging ability of Achillea wilhelmsii was determined as $0.08 \mathrm{mg} / \mathrm{ml}$ and it was found to be higher than the standards used BHA (0.07 mg / ml) and can be used in the medical field (Alfatemi et al., 2015). 
In our study, the cleaning efficiency of $A$. biebersteinii BHA and BHT is shown in figure 2. It was observed that the radical scavenging activity increased due to the increasing concentration. Quenching activities at $500 \mu \mathrm{g} / \mathrm{ml}$ which is the highest concentration for BHA, BHT, water extract and alcohol extract, respectively; we see it as $95.07 \%, 93.28 \%, 75.21 \%$ and $87.26 \%$. We can say that $A$. biebersteinii has high radical scavenging ability with this presented study.

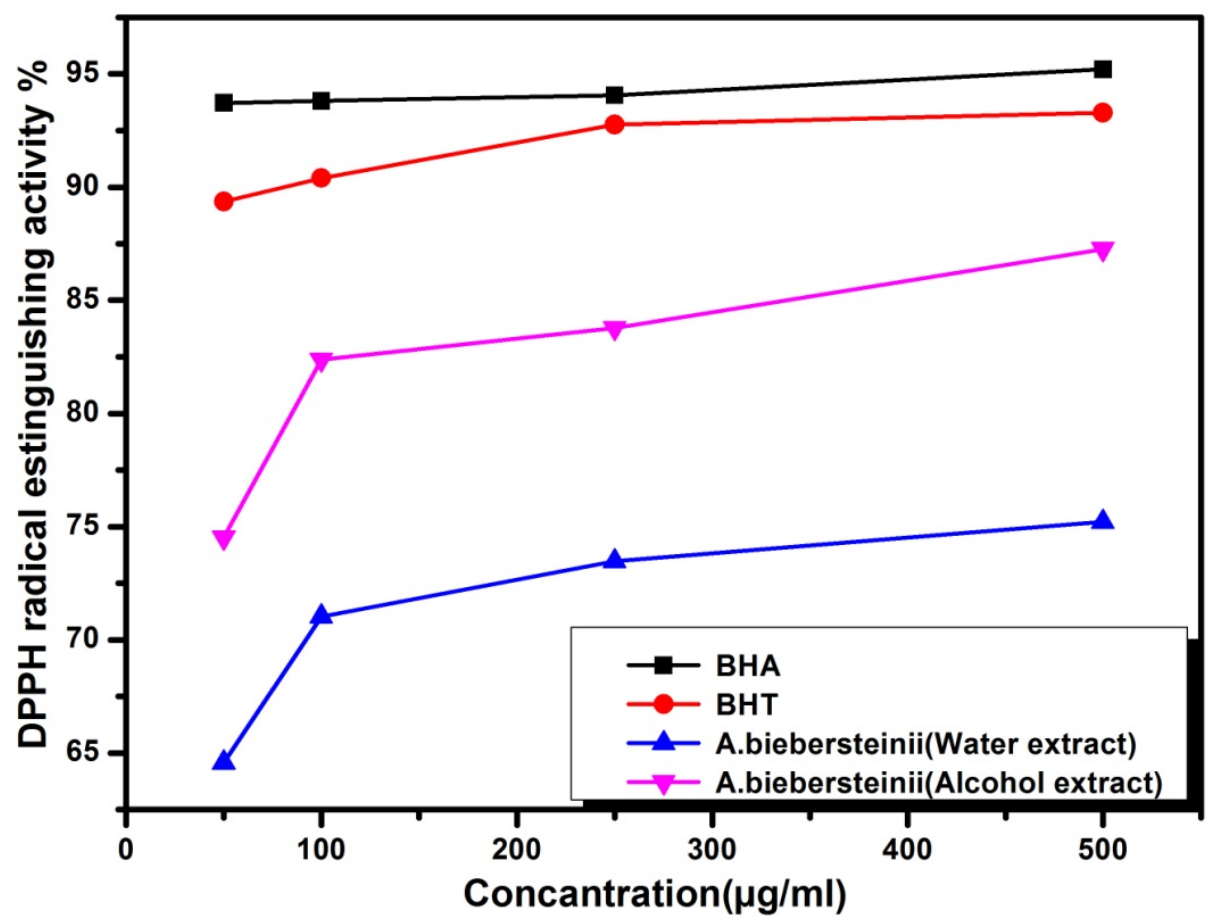

Figure 2. DPPH radical quenching activity

\section{Total flavonoid component assay}

The total flavonoid content is particularly linked to the antioxidant. Therefore, flavonoid contents are determined while looking at antioxidant activity (Kundakovic et al., 2005). In the determination of flavonoid content for Achillea millefolium, the flavonoid content of the methanol extract was found to be 41.2 \pm 1.7 (QE / g) (Eghdami et al., 2010). In our study, the total flavonoid component content of $A$. biebersteinii ethanol and water extract was calculated as equivalent to quarcetin. It was read at an absorbance of $415 \mathrm{~nm}$. The values of A. biebersteinii extract were plotted against increasing quarcetin concentration. (Figure 3) The total flavonoid component amount of the ethanol extract of the plant was found to be equivalent to $104.8814 \pm 31.7487 \mu \mathrm{g} / \mathrm{ml}$ quarcetin. Compared with other studies with Achillea species, it was seen that the plant in our current study has rich flavonoid contents.

Table 2. Total flavonoid component content of water and ethyl alcohol

\section{Total flavonoid ( $\mu \mathrm{gQEs} / \mathrm{mg}$ extract)*}

Water ekstract

Ethyl alcohol
$306.8412 \pm 18.47$

$104.8814 \pm 31.7487$

*: QEs, quercetin equivalents $\left(\mathrm{y}=355,37 \mathrm{x}+-23,191 \mathrm{R}^{2}=0.9952\right)$

Values are given as the mean and standard deviation of 3 parallel measurements. 


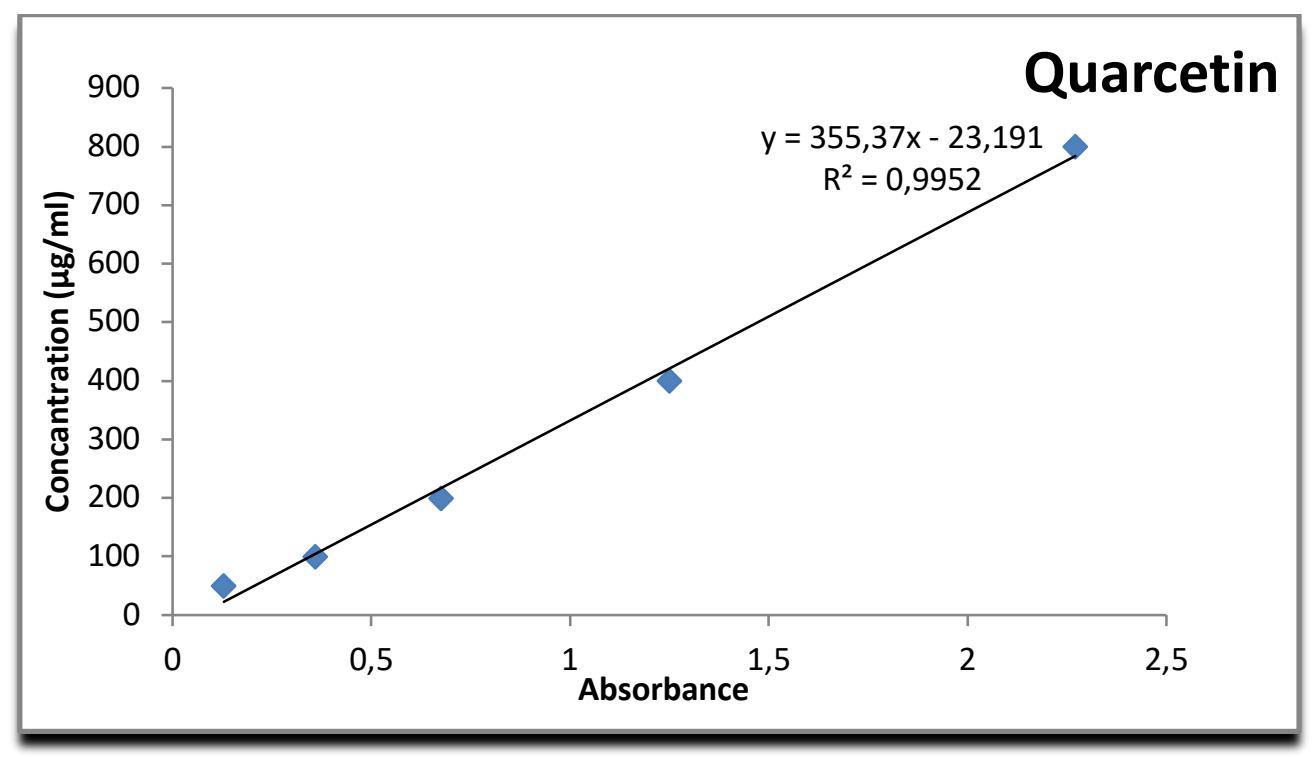

Figure 3. Quercetin standard chart for total flavonoid. Gallic acid standard chart for total phenolic. The coefficient of determination $\left(\mathrm{R}^{2}\right)$, which expresses the explanatory power of the model, was found to be 0.9952 .

\section{Total antioxidant capacity cuprac test}

Studies have shown that the Cuprac method is superior to other antioxidant tests (Gorinstein et al., 2006). In the study in which antioxidant activities of Achillea sivasica were examined, it was found that the contents of methanol were between $0.6 \pm 0.02$ and $0.94 \pm 0.02$ as a result of the cuprac test. (Haliloğlu et al., 2017). In our study, the absorbance measurements made on the reagent used in this analysis on A. biebersteinii are shown in the graphic. Compared to the reagents we used, good results were obtained due to the increase in the amount of ethyl alcohol and aqueous extract.

Table 3. Cuprac test results for positive controls and extracts. The average of 3 parallel measurements obtained from the results cuprac tests was taken as means $\pm \operatorname{SD}(n=3)$.

\begin{tabular}{lc}
\hline Extracts & $100 \mu \mathrm{g} / \mathrm{ml}$ \\
Ethyl alcohol & $0.78333 \pm 0.011$ \\
Water & $1.231667 \pm 0.019$ \\
BHT & $1.244 \pm 0.021$ \\
BHA & $1.630 \pm 0.034$ \\
$\alpha$-TOC & $1.02733 \pm 0.015$ \\
\hline
\end{tabular}

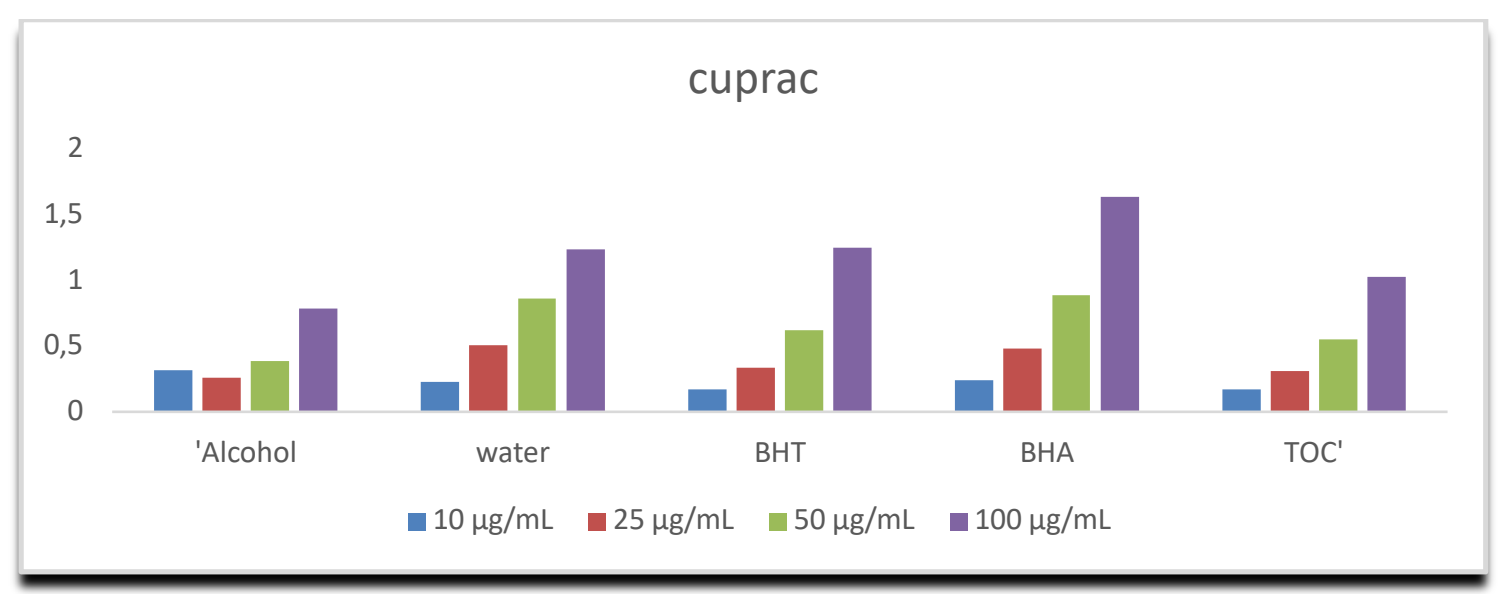

Figure 4. Cuprac test results at different concentrations 


\section{CONCLUSION}

Herbal medicines used in the world constitute a significant part of the total medicines. The damages caused by chemical drugs have led to the study of the therapeutic effects of herbs. These bioactive compounds, potentially as preservative ingredients, are also used as food additives. Important effects such as antioxidant, antimicrobial, anti-fungal and antibacterial have been discovered in most of the plants from the sufficient amount of phenolic structures it contains. Most Achillea species, which are rich in content, have proven these properties as a result of studies and have been used in folk medicine for a long time. In our study, we investigated the antioxidant parameters of A. biebersteinii, one of the Achillea species, and its effect on DPPH radical.

We know that the phenolic and flavonoid compounds contained in plants have potential as antioxidants. In the present study, the phenolic contents of. A. biebersteinii were calculated as equivalent to gallic acid. We see that the values obtained in ethanol and water extract are significant. The total flavonoid amount of $A$. biebersteini was found to be equivalent to $104,881 \pm 31,7487 \mu \mathrm{g} / \mathrm{ml}$ quarcetin for ethanol. We observed that the quenching activity of DPPH radical, especially the alcohol extract, was $\% 87$ at $500 \mu \mathrm{g} / \mathrm{ml}$. In our cuprac test, we found that our plant had very good values compared to BHT, BHA and $\alpha$-TOC 'used as reference. According to the results obtained, we believe that phytochemicals can be used as antioxidant agents in the health field. Considering the researches made with medicinal plants like this, it is predicted that it will provide more development in the field of medicine.

\section{REFERENCES}

Abd-Alla, H. I., Shalaby, N. M., Hamed, M. A., El-Rigal, N. S., Al-Ghamdi, S. N., \& Bouajila, J., 2016. Phytochemical composition, protective and therapeutic effect on gastric ulcer and $\alpha$-amylase inhibitory activity of Achillea biebersteinii Afan. Archives of Pharmacal Research, 39 (1), 10-20.

Akkol, E. K., Koca, U., Pesin, I., \& Yilmazer, D., 2011. Evaluation of the wound healing potential of Achillea biebersteinii Afan.(Asteraceae) by in vivo excision and incision models. Evidence-Based Complementary and Alternative Medicine.

Alfatemi, S. M. H., Rad, J. S., Rad, M. S., Mohsenzadeh, S., \& Da Silva, J. A. T., 2015. Chemical composition, antioxidant activity and in vitro antibacterial activity of Achillea wilhelmsii $C$. Koch essential oil on methicillin-susceptible and methicillin-resistant Staphylococcus aureus spp. 3 Biotech, 5 (1), 39-44.

Alhakmani, F., Kumar, S., \& Khan, S. A., 2013. Estimation of total phenolic content, in-vitro antioxidant and anti-inflammatory activity of flowers of Moringa oleifera. Asian Pacific Journal of Tropical Biomedicine, 3 (8), 623-627.

Altındağ, F., \& Özdek, U., 2021. Protective Eff ects of Chitosan and Chitosan Oligosaccharide on Sodium Fluoride-Induced Testicular Damage in Male Rats: A Stereological and Histopathological Study. Kafkas Univ Vet Fak Derg, 27(2), 83-189.

Altindağ, F., \& Rağbetli, M. Ç., 2021. The effect of maternal treatment with diclofenac sodium and thymoquinone on testicular parameters in rat offspring. Revista Internacional de Andrología. 19(1), $34-40$

Apak, R., Güçlü, K., Özyürek, M., and Karademir, S. E., 2004. Novel total antioxidant capacity index for dietary polyphenols and vitamins $\mathrm{C}$ and $\mathrm{E}$, using their cupric ion reducing capability in the presence of neocuproine: CUPRAC method. Journal of agricultural and food chemistry, 52(26), 7970-7981.

Ayeygin, K., Alp, H. H., Huyut, Z., Yıldırım, S., Altındag, F., \& Avci, V., 2021. The effects of CoQ10 supplement on matrix metalloproteinases, oxidative DNA damage and pro-inflammatory cytokines in testicular ischaemia/reperfusion injury in rats. Andrologia. 53: e13839 
Baharara, J., Namvar, F., Ramezani, T., Mousavi, M., \& Mohamad, R., 2015. Silver nanoparticles biosynthesized using Achillea biebersteinii flower extract: apoptosis induction in MCF-7 cells via caspase activation and regulation of Bax and Bcl-2 gene expression. Molecules, 20 (2), 2693-2706.

Barış, Ö., Güllüce, M.., Şahin, F., Özer, H., Kiliç, H., Özkan, H., \& Özbek, T., 2006. Biological activities of the essential oil and methanol extract of Achillea biebersteinii Afan.(Asteraceae). Turkish Journal of Biology, 30 (2), 65-73.

Eghdami, A., \& Fatemeh, S., 2010. Determination of total phenolic and flavonoids contents in methanolic and aqueous extract of Achillea millefolium. The Journal of Organic Chemistry (2), 81-84.

Gorinstein, S., Leontowicz, M., Leontowicz, H., Najman, K., Namiesnik, J., Park, Y. S., \& Trakhtenberg, S., 2006. Supplementation of garlic lowers lipids and increases antioxidant capacity in plasma of rats. NutritionResearch, 26(7), 362-368.

Haliloglu, Y., Ozek, T., Tekin, M., Goger, F., Base, K. H. C., \& Ozek, G., 2017. Phytochemicals, antioxidant, and antityrosinase activities of Achillea sivasica Çelik and Akpulat. International Journal of Food Properties, 20(1), 693-706.

Hammad, H. M., Albu, C., Matar, S. A., Litescu, S. C., Al Jaber, H. I., Abualraghib, A. S., \& Afifi, F. U., 2013. Biological activities of the hydro-alchoholic and aqueous extracts of Achillea biebersteinii Afan.(Asteraceae) grown in Jordan. African Journal of Pharmacy and Pharmacology, 7 (25), 16861694.

Keser S., Celik, S., Turkoglu, S., Yilmaz, Ö., \& Turkoglu, I., 2013. Antioxidant activity, total phenolic and flavonoid content of water and ethanol extracts from Achillea millefolium L. Turkish Journal of Pharmaceutical Sciences, 10 (3), p. 385

Kundaković, T., Dukić, N. M., \& Kovačević, N., 2005. Free radical scavenging activity of Achillea alexandri-regis extracts. Fitoterapia, 76 (6), 574-576.

Lobo, V., Patil, A., Phatak, A., \& Chandra, N., 2010. Free radicals, antioxidants and functional foods: Impact on human health. Pharmacognosy Reviews, 4 (8), 118.

Mert, H., İrak, K., Çibuk, S., Yıldırım, S., Mert, N., 2020. The effect of evening primrose oil (Oenothera biennis) on the level of adiponectin and some biochemical parameters in rats with fructose induced metabolic syndrome. Archives of Physiology and Biochemistry. 1-9.

Meydan, İ., Seckin, H., 2021. Green synthesis, characterization, antimicrobial and antioxidant activities of zinc oxide nanoparticles using Helichrysum arenarium extract. Int. J. of Agr. Env. and Food Sci. 5(1), $33-41$.

Meydan, İ., Kizil, G., Demir, H., Toptanci, B. C., \& Kizil, M., 2020. In vitro DNA damage, protein oxidation protective activity and antioxidant potentials of almond fruit (Amygdalus trichamygdalus) parts (hull and drupe) using soxhlet ethanol extraction. Advances in Traditional Medicine, 1-9.

Mirahmadi, S. F., \& Reza, N., 2017.Chemical composition, phenolic content, free radical scavenging and antifungal activities of Achillea biebersteinii. Food Bioscience, 18,53-59.

Oke, F., Aslim, B., Ozturk, S., \& Altundag, S., 2009. Essential oil composition, antimicrobial and antioxidant activities of Satureja cuneifolia Ten. Food Chemistry, 112(4), 874-879.

Ozdek U, Seckin H, Cibuk S., 2020 Investigation of Antimicrobial Effects of Amygdalus Trichamygdalus (Sweet Almond) and Amygdalus nana L. (Bitter Almond) Plants. Van Vet J. 31 (1), 22-26.

Özyürek, M., Güçlü, K., \& Apak, R., 2011. The main and modified cuprac methods of antioxidant measurement. Trends in Analytical Chemistry, 30 (4), 652-664.

Seçkin, H., Meydan, İ., 2021. Synthesis and Characterization of Veronica beccabunga Green Synthesized Silver Nanoparticles for The Antioxidant and Antimicrobial Activity Turk J. Agric. Res. 8(1), 49-55.

Sevindik, H., Güvenalp, Z., Yerdelen, K., Yuca, H., \& Demirezer, L. Ö., 2015. Research on drug candidate anticholinesterase molecules from Achillea biebersteinii Afan. using by molecular docking and in vitro methods. Medicinal Chemistry Research, 24(11), 3794-3802.

Sökmen, A., Sökmen, M., Daferera, D., Polissiou, M., Candan, F., Ünlü, M., \& Akpulat, H.A., 2004. The in vitro antioxidant and antimicrobial activities of the essential oil and methanol extracts of Achillea biebersteini Afan(Asteraceae). Phytotherapy Research, 18(6),451-456. 
Teixeira, B., Marques, A., Ramos, C., Neng, N.R., Nogueira, J. M. F., Saraiva, J. A., \& Nunes, M. L., 2013. Chemical composition and antibacterial and antioxidant properties of commercial essential oils. Industrial Crops and Products, 43, 587-595.

Varasteh-Kojourian, M., Abrishamchi, P., Matin, M. M., Asili, J., Ejtehadi, H., \& Khosravitabar, F., 2017. Antioxidant, cytotoxic and DNA protective properties of Achillea eriophora DC. and Achillea biebersteinii Afan extracts: A comparative study. Avicenna Journal of Phytomedicine, 7 (2), 157.

Yildirim, B., Ekici, K., \& Rezaeieh, K. A. P., 2015. Volatile oil components and antibacterial activity of Achillea biebersteinii Afan. from lake Van Basin, Turkey. Asian Journal of Chemistry, 27 (12),4686.

Zengin, G., Bulut, G., Mollica, A., Haznedaroglu, M. Z., Dogan, A., \& Aktumsek, A., 2017. Bioactivities of Achillea phrygia and Bupleurum croceum based on the composition of phenolic compounds: In vitro and in silico approaches. Food and Chemical Toxicology, 107, 597-608.

Zhishen, J., Mengcheng, T., \& Jianming, W., 1999. The determination of flavonoid contents in mulberry and their scavenging effects on superoxide radicals. Food Chemistry, 64 (4), 555-559. 